\title{
Paideusis
}

\section{Schooling as a Journey in Humanization}

\section{Douglas Stewart}

Volume 13, Number 2, 2000

URI: https://id.erudit.org/iderudit/1073013ar

DOI: https://doi.org/10.7202/1073013ar

See table of contents

Publisher(s)

Canadian Philosophy of Education Society

ISSN

0838-4517 (print)

1916-0348 (digital)

Explore this journal

Cite this article

Stewart, D. (2000). Schooling as a Journey in Humanization. Paideusis, 13(2),

5-22. https://doi.org/10.7202/1073013ar

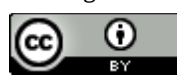

This document is protected by copyright law. Use of the services of Erudit (including reproduction) is subject to its terms and conditions, which can be viewed online.

https://apropos.erudit.org/en/users/policy-on-use/
This article is disseminated and preserved by Érudit.

Érudit is a non-profit inter-university consortium of the Université de Montréal, Université Laval, and the Université du Québec à Montréal. Its mission is to promote and disseminate research.

https://www.erudit.org/en/ 


\section{Schooling as a Journey in Humanization}

\section{Douglas Stewart, University of Regina}

In this paper I claim that the primary "good" at which schools should aim is the humanization of children and young people, or of helping them to become persons more fully. Much in this thesis turns on what it means to be a "person" and on what counts as the development of humanness or personhood. I shall address these and related questions presently. The journey of humanization is, of course, life-long. It neither begins nor ends with schooling and while other societal institutions are (or ought to be) concerned with the development of humanness, school represents one of the most critical phases of the journey. ${ }^{1}$ Much of the ground I cover is familiar territory in philosophy of education, including perhaps the basic idea itself - schooling as the humanization of students. It is timely, however, that this matter be revisited. Schools are under relentless and mounting pressure from various sectors of society (including provincial governments) either to take on more tasks and be ever more responsive to rapidly-changing external conditions, or to radically shift some of their focus and emphasis, or both, which means that the idea of school as a primary agent of humanization cannot be taken for granted. In fact, it is facing enormous competition and may be at risk of disappearing altogether.

At least one provincial ministry of education ${ }^{2}$ has recently been prompted to establish an independent task force and public dialogue on the role of the school, hoping (one assumes) to present a clearer understanding to the ministry of what schools should be doing in light of the many demands and expectations they face.

My thoughts in this paper have been occasioned by these concerns and developments.

\section{A Canadian Context}

It is useful to begin with a brief historical account of schooling. For this purpose I have English Canada primarily in mind, from roughly the period that Egerton Ryerson was Chief Superintendent of Schools in Ontario (1846-76) to the early $20^{\text {th }}$ century. Ryerson's work in achieving a uniform and centralized system of schooling (public and separate) is not untypical of the era and had a considerable impact on subsequent developments in public education in other regions, the prairies in particular (Child, 1978). During this time Canada was struggling to define itself as a nation in the midst of an emerging industrial economy, massive 
immigration from Britain and Ireland (and later central and eastern Europe), the threat of American attitudes and values, the French fact, and conflicts between church and state over control of education. Such were the dominant social, economic and political conditions out of which the roles and practices of common (elementary) schooling were forged. Despite the relatively shaky state these schools were in ${ }^{3}$, the resulting tasks they had to shoulder were nonetheless formidable.

From a political perspective, and in keeping with the national dream of a united British Canada, schools were singled out as the primary institution for developing a national identity or consciousness informed by Anglo-Christian values and a deference to the ideals of British monarchy and parliamentary democracy. Achieving this goal required a curriculum of literacy and numeracy, British history, moral and religious character, and civic duties and responsibilities. The Victorian virtues of loyalty, piety, frugality, cleanliness, industriousness and respect for adult authority, along with an array of patriotic symbols, songs and stories all played an indispensable role in the early schooling of English-speaking Canadian children as well as children of minority cultures (Tomkins, 1986).

With respect to the social and economic conditions, forces of industrialization had brought major changes to English Canadian life-styles as populations shifted from rural to urban areas in search of new employment and better living standards. Whatever the benefits gained, the social costs as measured in terms of rising rates of alcoholism, the growth of poor and unhealthy living conditions in urban pockets, the consequences for family life of separating the workplace from the home, and the industrial use of child labour, could hardly be ignored. Beyond the broadly political menu of citizenship preparation, patriotism, and moral formation, common schools were expected to respond to these social, economic, and vocational concerns as well. Thus girls were taught basic homemaking (and occasionally commercial) skills, and boys, basic manual and technical skills (re-enforcing traditional sex roles in the process). Health habits were targeted through classes in hygiene and cleanliness, while habits of self-control and abstinence were nurtured in part through programs of temperance education that were vigorously promoted by special interest groups such as the Women's Christian Temperance Union (WCTU) (Sheehan, 1981).

With few exceptions, I would argue (see note 4 ), the problems faced by schools in the $19^{\text {th }}$ and early $20^{\text {th }}$ centuries differed in degree rather than kind from those facing schools today. Apart from heated and familiar debates over textbook policies, the role of religion in school, and control of curriculum, two issues stood out: (i) the inequality of educational opportunity and life-chances for children from 
working and lower middle-class homes, and (ii) a hard-nosed assimilationist policy directed at Indigenous peoples and the growing presence of non-Anglo European cultures. The first of these had its roots in the structure of schooling itself, a quasi two-tracked system consisting of the common schools for the masses (as noted) and a scattered network of relatively few elite grammar schools and private academies for children from well-off homes. Only the latter schools taught the liberal and classical subjects necessary for entry into higher education and the learned professions, and were, as a result, the gate-keepers to better and more satisfying ways of life. Laudable as the robust attempts of Ryerson and his colleagues were to democratize public education, their reforms did not succeed in the elimination of educational injustice.

The second issue involved the responsibility that national and provincial governments vested in schools (both state and church-run) to assimilate Indigenous and minority children alike to the dominant Anglo-Celtic culture. This policy had complex origins, not the least of which were an overly-zealous desire of the establishment for a strong and united Canada under a set of common beliefs and ideals, and an egregious lapse of moral conscience by those in power (however well intentioned they claimed to be) that showed little trust and respect for the "culturally different". The painful disruptions to innocent Indigenous and other children and their families, and the anguish they experienced as a result of systematic cultural and emotional abuse practiced by schools, is a shameful chapter in the history of Canada and Canadian education (see for example Milloy, 1999).

\section{Humanization and Schooling: an interlude}

"Humanization" and "schooling" is an association that may not easily or readily spring to mind for many. There is relatively little evidence of it in earlier days of public education in Canada as we have just seen, concerned as it was with national consciousness-raising and social control, nor is the current situation of schooling very much at ease with this association either'. Public schooling continues to be valued primarily as a means for achieving a variety of extrinsic ends -- political (to make the nation more competitive), socio-economic (to improve living standards), vocational (to prepare a skilled workforce) -- rather than as an institution for humanization in its own right. Instrumental or utilitarian views of schooling generally work against the notion of individual cultivation of humanness as an end in itself.

A vivid reminder of this situation may be found in recent stances of provincial ministries of education. According to Ken Osborne (1999), for the past 
decade ministries have been urging Canadian schools to place greater curriculum emphasis specifically on literacy, computers, mathematics, science, problemsolving, decision-making, teamwork and entrepreneurship, as a means of producing a "skilled and flexible workforce, comfortable with sophisticated technology" (p.19); and, to form closer ties with business and corporate communities. The intent of these initiatives (one assumes) is roughly two-fold: to make a more competitive nation in the global market; and to ease the burden on provincial budgets by down-loading some costs of public education to the private sector. This is a policy that is both dangerous and misleading. It is dangerous because of its potential for eroding school autonomy and creating school environments that influence the consumer choices of young people. For publiclyfunded schools to make market targets out of children is a clear violation of the trust in which such schools are held, and is (thus) a morally offensive practice. The policy is misleading and short-sighted, on the other hand, for glossing over the fact that jobs in the high-tech field are fewer than those in the unskilled and semi-skilled low-wage sector, and that only a minority of young people will find work that is challenging and rewarding in the former (Osborne, 1999).

The conclusion to draw from this is not that schools should defy the ministries and concentrate on whatever skills and attitudes might be useful for employment in low-waged, semi-skilled areas, but that schools should not be teaching specific workplace skills at all. This is a matter best left to employers themselves. Schools instead should be intently concerned with their mission of humanness. If Osborne's analysis is correct, there is all the more reason for the humanization of schooling so that the lives of those employed in un-skilled or semiskilled areas can be as meaningful and fulfilling as possible, and ones in which their spirits can be sustained and nourished outside their workplace. The social-cultural gap among those situated in the various sectors of work might also possibly be narrowed as a result. Moreover, humanization is arguably the best form of preparation for those aiming at high-tech jobs, contra the views of ministries, although these thoughts admittedly put a instrumental spin on the idea of schooling as humanization not exactly in keeping with the general thrust of this paper.

Finally, with the dehumanizing and environmentally harmful effects ${ }^{7}$ that global markets, world trade organizations and fast-paced electronics industries are creating, any conception of schooling that makes the cultivation of humanness an intrinsically worthwhile end is all the more compelling and urgent. 


\section{Humanization and Schooling: an analysis}

To this point I have been assuming some familiarity with the idea of humanization on the reader's part. It is time I clarified and defended this notion more fully. For this purpose I draw selectively on the work of both Richard Pring (1992; 1995) and John White (1995). My list of human qualities or characteristics involved in becoming persons more fully, i.e., in human flourishing, is undoubtedly incomplete. It does not include a reference to physical health and fitness for example, or to the possession of humour, which some might argue for inclusion and to which I would not strenuously object. However the list succeeds (I believe)in capturing at least the main or most central characteristics or features of "humanness". These include: the capacities to acquire and develop knowledge and understanding, including self-knowledge and self-respect; the capacities to think clearly and critically, to exercise an independence or autonomy of judgment, to frame purposes, goals, and plans; the capacities to develop moral virtues (e.g., concern, compassion, self-discipline) and grow in moral awareness, conduct and feeling; the capacities to imagine and empathize; to experience and refine emotion ${ }^{8}$ including the feelings of "wonder" at the contingencies of the natural world and of "attachment" to nature as our dwelling place (White, 1995); to be creative and to appreciate goodness and beauty; to form congenial attachments to social groups, to care about and participate in community, and to communicate effectively. Put simply, the more one develops these qualities and the will or resolve necessary to exercise them as well as possible, the more fully a person one becomes, or the more fully in touch one is with one's humanness and the human condition.

From this we may infer that a paucity of knowledge, a narrowness and rigidity of outlook, a possession of ill-grounded beliefs, moral blindness (including a disrespect for the natural environment), lack of empathy, absence of critical and independent judgment, social aloofness, disregard for human creativity, emotional insensitivity or instability, etc., are all manifestly incompatible with the ideals and values of humanness in the fuller sense. We may also infer that "humanization" (as set forth here) and "education" (understood as a family of theoretical or truthseeking activities essential to rational life (Peters, 1966; 1977)) are not synonymous, though they incorporate much common ground. "Humanization" is the wider notion of the two however. To be an educated person one need not have experienced or be open to a wider range of human emotion; nor does "education" entail participation in congenial forms of social life and formation of social attachments, or perhaps even a moral commitment ${ }^{9}$, all of which I claim to be an integral part of "humanization". Thus in characterizing schooling as a journey in 
"humanization" rather than a journey in "education" I am making a plea that all qualities of humanness, not just the more cognitive or truth-seeking ones, central though they are as I presently show, need to be addressed.

While it is important to acknowledge that "humanization" understood as "becoming persons more fully" is a matter of degree (obviously no one is born fully a person, or without any capacity for development of intellect and emotion), such acknowledgment might nonetheless open the way to gross mistreatment of others. Those who would consider some individuals or groups (eg, women, Blacks, gays, the disabled) to be not fully human might (ironically) seize upon the idea of "humanization" as a means to justify the oppression, exclusion or segregation of such individuals or groups". Any account of "humanization" therefore must be understood to be well embedded within a framework of basic moral principles, in particular the principles of respect for persons and of justice. The first is required to ensure that every individual (regardless of level of human development or human capacity) has a basic right to be treated with the respect and dignity that is their inherent due as human beings, and to show that those who would take the "not-yetfully-human" idea to justify oppression or exclusion are profoundly immoral in their beliefs and actions. The second principle (in conjunction with the first) is to ensure an equal opportunity to become as fully human as possible and therefore an equality of access to the conditions under which the individual cultivation of humanness can be best achieved or at least best approximated. Justice (here) does not imply an equality of outcomes. The idea of "equal outcomes" (and for that matter "equal inputs") is particularly insensitive both to the notion of humanization as being a matter of degree and to the reality of genuine differences in talents, interests, and diversity of student conditions and needs. What justice in the context of schooling for humanization demands is an equitable distribution of pedagogical resources and appropriate learning environments (with the necessary funding) so that opportunities for those students with the greater barriers to learning and growth are more equalized as a result ${ }^{\prime \prime}$.

At the core of the conception of "personhood" is mind (intellect) understood as consciousness or awareness (Peters, 1966). The journey of humanization is (in part) necessarily mind-centred, aimed at the development of differentiated consciousness or awareness. This does not imply that the role of schools is to hone young people for a life of the mind, or that schools should be institutions of intellectual elitism (see Entwistle, 1997). What the journey implies (rather) is the metaphysical claim that mind is basic or fundamental to personhood in all its dimensions - cognitive, emotional, social, moral and spiritual -- and that if 
schools are to be institutions of humanization and take this role seriously, their concerted attention is eamestly required in heightening the consciousness or awareness of each individual. To empower individuals with greater meaning and sense of the world, and of who they are, a progressive initiation into the achievements of the human mind and spirit is required.

These achievements (it is generally agreed) are embodied in a number of basic and relatively distinct symbolic systems variously referred to as traditions or frameworks of thought and feeling (Pring, 1995), forms of knowledge and understanding (Hirst, 1974" ), or "conversations" of human kind Oakeshott (1962; 1991). While not identical in points of detail, these maps of human experience include at least the following realms: the natural sciences, the human or social sciences, mathematics, the expressive arts and literature, moral understanding and vision, religious understanding, and philosophical reflection. Oakeshott's metaphor of "conversations" arguably provides the more sensitive and perhaps most comprehensive account overall; and it should have succeeded in clarifying and dispelling some of the misconceptions associated with traditions of human thought and feeling -- that they are Westernized, genderized, static, and self-contained -and have advanced instead the more defensible view of them as inclusive, dynamic, and evolving ${ }^{13}$. Unfortunately some of these misconceptions persist.

The link between qualities of humanness or personhood and the traditions or conversations of thought and understanding is conceptual. That is, the idea of getting children inside the realms of mathematics, natural science, the human or social world, of artistic expression and appreciation, of morals, etc., and getting them engaged in the thinking, doing, making, and feeling that is necessarily required, just is a central part of "humanization". The more progress made in mastering the discourses of each tradition, i.e., the distinctive languages, concepts, judgments, methods of inquiry, modes of valuing and evaluation, and the dispositions (intellectual and moral) involved ${ }^{14}$, the greater one's human enrichment must be. Humanization is not (of course) an easy task for schools and teachers to tackle. The "conversations" may initially seem strange to children and not readily accessible to them, yet it is hard to imagine many objectives apart from those embodied in the basic forms of human thought and experience more in line with the idea of individual cultivation and enrichment ${ }^{15}$.

It might be argued that the school as an agency of humanization is an idea whose time has passed. According to some (Elkind, 1995; Cunningham, 1995), the stage of childhood is rapidly disappearing in a postmodern world and with it the status of children is obviously changing. Witness the emergence of youngsters wise 
in ways of the streets, experienced as care-givers (of younger siblings), skilled in information technology, increasingly aggressive in their demands for greater access to adult worlds and for a greater share of power. Sophisticated and bold as their actions and appearance may be, their journey in becoming persons more fully has scarcely begun. Young people have much to learn and understand of the natural, human, and moral-social realms that constitute their domicile, and much else besides. Information is not necessarily knowledge, especially in a digital world where it arrives in story-less forms and divorced from context or purpose (Postman, 1999). Obtaining "facts" in an information age is not the problem; how to analyze and make sense of them is. Without frameworks of knowledge and understanding to sift truth from error, fantasy from reality, to think critically and creatively, exercise an independence of thought and judgment in facing the information glut, students will have made very little progress in their journey of cultivation and enrichment.

\section{Barriers to Humanization:}

I have argued that the primary "good" at which schools should aim is helping students become persons more fully. Obstacles of various kinds stand in the way of such a project. The presence of blatant instrumental or utilitarian attitudes towards schooling, as expressed for example in terms of market economies to which I alluded earlier (see "Humanization and Schooling: an interlude"), is a case in point. There are additional obstacles to the school's cultivation of humanness I wish to consider briefly.

(a) Inhospitable Leaming Environment

The other great difference between schools of the $19^{\text {th }}$ and early $20^{\text {th }}$ Centuries and those of the present ${ }^{16}$ is the transformation of classrooms from regimented and authoritarian places of learning which generally worked against the development of humanness, to predominately child-centred and democratic learning environments rooted in values of community, respect, concern, and trust. As result of these "progressive" measures, children today enjoy a freedom of expression and movement in classrooms unknown to their predecessors, while schools have become much more responsive to individual differences in learning styles and diversities of various other kinds, and much more cautious and gentle in the administration of discipline.

Various explanations for these "humanizing" transformations can be advanced, not the least of which is the gradual but general acceptance in Canadian schooling (particularly at the elementary level) of Dewey's philosophy of 
progressivism and democratic community (Dewey, 1938; 1940). There are, too, the efforts that schools have more, recently made through various compensatory programmes to help offset the negative impact of poor socio-economic home conditions on children's motivation to learn, as well as efforts to achieve greater parental involvement in children's schooling, to provide classrooms that are safe ${ }^{17}$, and to combat racist and other undesirable social attitudes. However, if having achieved classroom environments that are more humane there is a reluctance (or hesitancy) of teachers and schools to initiate children into the "conversations" of human understanding for fear of the demands this might place on children, or of damaging their self-esteem or curtailing their "fun", then the achievement of such environments is a very hollow victory indeed.

(b) Flight From History

The situation concerning history in Canadian schools is vexing. Osborne (1999) reports that nearly half the ministries of education at present do not think that society needs all Canadians to know and understand their country's history. This certainly has a ring of truth to it as far as the province of Saskatchewan is concerned. The government's curriculum reform initiatives which began in the 1980 's shunned the subjects of history and geography at least in name and partly in content, replacing them in its new K-12 compulsory core with "social studies"18. Pundits at the time had pronounced that history was not sufficiently adept at nurturing the problem-solving and decision-making skills necessary for students heading into the $21^{\text {st }}$ Century, or that its (alleged) emphasis on facts, dates, and rote memorization made history insufficiently enlightened as an area of study. A preoccupation with facts and dates if true is, of course, fair criticism of the organization and teaching of the subject. But the hasty foreclosure on history proper without a fair and open-minded examination of other ways in which it could be organized and delivered more effectively, was unjustified. The counter-argument that social studies can achieve a broad and coherent understanding of human social experience despite the limited and fragmentary glimpses of history it actually permits (Egan, 1983 ; 1997), bears no more scrutiny than the argument against giving history proper a central place in a core curriculum.

To know the history of one's nation (and aspects of other national histories relevant to it) as part of the human story is arguably a right of all students in terms of their humanization and understanding of the human condition. Without history they are largely ignorant of the purposes, struggles, triumphs, and tragedies which have informed a nation's development, and they lack any grounded vision of a nation and what it could be. It is through history that students also develop a deeper 
sense of their cultural origins and identities than they are otherwise likely to achieve through multi-cultural education or social studies. And, in some cases, as with Aboriginal children who are almost completely unknowing of their cultural history and the treatment their forbears received, a fair and forthright study of history could be an immense help in their coming to understand the "reasons why" of their present situated-ness as Indigenous peoples.

The diminishment of history in schooling plays havoc as well with students' conceptions of time. Events of only three or for years ago are likely to be dismissed as "old" and treated as not worth knowing or heeding 19 . This is a recipe for the gradual disappearance of memory (both individual and collective), and for the repetition of mistakes in social and political life. To live life without memory is, to that extent, to be diminished as a person.

(c) Being "Skilled" to Death

The humanization of students is also placed at risk by the obsession of educators and teachers with the notion of "skills" or "know hows". Entities that are not skills are routinely and misleadingly characterized as such. Two common examples of this error are found in the portrayal of critical and creative thinking as generic skills ${ }^{20}$. Criticalness and creativity are not skills nor are they reducible to skills (though skill elements may well be involved); rather they are complex achievements and activities of mind and character. Their achievement presuppose a background of relevant forms of knowledge and understanding, a conceptual awareness and ability to make relevant distinctions and demarcations, a knowledge of standards, the exercise of judgment and imagination, and the possession of intellectual and moral dispositions such as commitment to evidence and argument, open-mindedness, fair-mindedness, honesty, perseverance, etc, (see Siegel, 1993; Bailin, et.al., 1999). That one can think critically in mathematics (for example) does not entail that one can think critically in history, drama, literature, biology or technology because the forms of knowledge involved and the central concepts, evidence, methods of inquiry, criteria of judgment (etc.) differ in each case. Thinking critically or creatively in any domain or inter-disciplinary field at least requires that one be "conversant" in the relevant language(s) and concepts. Thus to reduce critical or creative thinking to the level of "skill" and to treat them as generic is to distort and transform what are distinctively human achievements into mechanistic-like processes and exercises that leave little scope for expressions of the human spirit to more genuinely and freely emerge.

(d) Failing at Transcendence

One aspect of this barrier is the waste, or the potential for waste, when 
children are not challenged by their schoolwork. As noted in (a) above, this may happen for a variety of reasons but one of the more common (in my observation) is that of "re-teaching" children what they already know either from everyday experiences and interactions outside school, or as a result of coverage in previous years of schooling, or both. Failure to move children in a timely manner beyond their present levels of experience or learning, to have them make breaks with the "everyday" or "mundane" and enter realms of understanding initially strange or foreign to them, is to risk the onslaught of boredom and a deadening of spirit. Such conditions are mis-educative and de-humanizing.

Another dimension to this barrier is what seems to be the official neglect by ministries of education of "understanding" (as a central objective of humanization). In the curriculum and related documents that ministries produce, the objectives of "knowledge", "skills" and "attitudes" are easily the most frequently-cited objectives, while "understanding" is seldom granted the light of day. The omission is critical. It suggests to teachers and others (or at least to those who take such materials at face value) that traditions of human thought and understanding, the objectives of coming to see aspects of the world in all their relatedness, of realizing new meanings and new ways of thinking and feeling, of making relevant distinctions, and so on, can be more or less shelved in the schooling of children. And it suggests that this can be done with the tacit blessing of ministries and without concern for the loss it would mean to the individual cultivation of humanness.

(e) Being Pulled in Many Directions at Once

With changes to the structure of family life and the socio-economic dislocations experienced by many families ${ }^{21}$, more and more children are coming to school deficient not only in sleep and nutrition but in manners and morals, in respect for legitimate authority, and in self-discipline; and they are coming from social environments that are often very different from the environment of the school. Added to this is the mounting support (if not demand)in society for the policy of "full inclusion" of special needs children regardless of type or severity of disability (Lupart, 2000). While this support is grounded in a belief of social justice, i.e., that all special needs children have an equal right with "regular" children to the cognitive, social and emotional benefits of being fully a part of normal classrooms, the policy places enormous demands and stress on teachers with which they are not trained to cope (see Kauffman and Hallahan, 1995). A further (and persistent) belief of society is that schools should be considerably more involved in combating the problems of AIDS, drugs, teen violence and teen 
pregnancies $^{22}$.

Schools cannot be all things to all people however, nor can teachers reasonably be expected to double as social workers, nurses, or psychologists and at the same time hope to succeed well as agents of humanization in line with their own professional training. This may strike some as strange or even paradoxical. In my analysis of "becoming persons more fully" I intimated that the achievement of manners, morals, self-discipline, and of living in community are all part of the social dimension of humanization and individual well-being. And, are these features not typical of the objectives of (school) socialization? This is true, but for reasons cited above the division of labour for the socialization of children has become quite uneven across the home, school and community, with the school arguably shouldering a much greater load than it has in the past. As a result, the epistemological role of schooling which is critical to the journey of humanization is at risk of being further eroded (and perhaps dangerously so) because of the time and energy required in dealing with the added socialization of students and the personal and social problems they bring with them to school. The more that schools are stretched in these directions, especially without the needed expertise and support of professional agencies in the wider community, the more that teachers are prohibited from providing a sustained and focused effort in their central mission of engaging students in the "conversations" of humankind.

\section{Concluding remarks}

I shall end with a few further observations concerning socialization and humanization, and by advancing a modest proposal to counter some of the barriers to humanization of the types found in (a) and (e) in particular.

Socialization is held in the popular mind consistently to be a good reason for schooling, and to many it is the school's primary (or only) goal or purpose. Richard Rorty (1996) surely lends credence to this belief with his idea that the socialization of children (under which he includes cultural literacy along the lines advocated by Hirsch, 1987) is all that schools should really be expected to handle. His views seem unduly narrow and limited however; and they may have neglected the idea that outside social agencies could more adequately treat the personal and social problems of children, thus freeing schools to attend more fully to other forms of individual cultivation for which they are best suited. Other philosophers (e.g., Nyberg and Egan (1981)) argue that socialization and education are mutually at odds in their aims (social conformity versus individual autonomy, to put it roughly) and that socialization is thus a barrier to education and, I assume, to fuller 
humanization as well. Depending on how "socialization" is taken, however, this conclusion need not follow. As suggested in (e) above, should socialization be construed as reasonable processes by which youngsters learn how to get along with others, the importance of human association and attachment, how to communicate effectively, and the basic cultural, social, and moral beliefs of society, then to that extent socialization is surely a necessary part of the journey in humanization. Indeed, were some of these aspects of human development to be ignored in the early going it would be difficult to see just how becoming persons more fully could actually get off the ground.

As a modest proposal for dealing with some of the barriers to humanization in the context of schooling, I suggest the following. First, that beyond the task of normal socialization, schools should not (in fairness) have to be saddled with the complexities of the personal or psychological and social problems of students, nor with meeting the other basic needs the modern family is not adequately addressing. Second, it is the departments of health, social welfare, and justice in the provinces that should have the primary responsibility for addressing these problems and needs, given that they (unlike schools) have the relevant expertise and professional training. This will require a heavier commitment of these agencies to families of poverty (and others) than what has heretofore been forthcoming in most provincial jurisdictions, as well as a concerted effort of the agencies to work in a co-ordinated and co-operative manner with schools. Third, that resource persons from these agencies be housed under the same roof as the school ${ }^{23}$ so that they can provide the necessary professional support services on-the-spot to children "of need", and do so in an efficient manner with as little disruption as possible to the integrity of the school day or to the learning of the students involved. Whether every school should be "transformed" into a learning-cum-social-services centre is unlikely, but that, in any case, would depend on location, demographics, socio-economic conditions, etc., of a school region or district.

In whatever way barriers to humanization are to be overcome, the journey by which youngsters are progressively put in touch with their humanness must be one of enlightenment; one that eschews a narrowness and rigidity of outlook or perspective and that takes them beyond their present experiences of the local and particular (Bailey, 1984) into wider frameworks of human understanding and feeling. As a journey of enlightenment, humanization is about freeing the traveler from misconception, prejudice and forms of ignorance, and opening visions to new meanings and understandings and (possible) ways of life heretofore outside their present ken or interests. 


\section{Notes}

1. I do not of course mean to imply that those in the world who never attend school must therefore be non-human or non-persons. Humanization as a journey in becoming persons more fully has to do with the types and qualities of experiences, encounters, interactions, engagements, etc., an individual has with the natural and human worlds, and the types and quality of learning therefrom, whether within or outside of schooling. My point is that if we are to have schools at all, humanization should be their chief aim. It does not follow that the only way to become more fully human is to be "schooled".

2. Saskatchewan Education, 1999. The final report of the Task Force is due December 2000.

3. "Many teachers in the common schools, which grew apace during Ryerson's superintendency, had little more than an elementary education, and most had no prior preparation for teaching. Teachers' complaints of overwork, poor salaries and unruly pupils were largely ignored....Learning resources were scarce and the curriculum seldom took into account the linguistic and cultural backgrounds of non-Anglo-Saxon children" (Carney, 1995, pp. 17-18).

4. Perhaps the greatest difference between schools then and now is the radically changed policy towards children of minority cultures. By the time Canada officially had become a muiti-cultural nation in 1971, the former assimilationist practices of schooling to make all children the "same" by promoting conformity to a dominant ideology could no longer be countenanced. Under multi-culturalism, schooling has become a celebration of diversity and a voice for the promotion of tolerance, anti-racism, and respect for differences. The practices of multi-cultural education, however, are not unproblematic. In the exuberance of schools to honour cultural diversity the common humanity of children can easily be overlooked; and the common moral beliefs, laws and institutions needed by a plural society to survive can too easily be ignored for fear of causing offense.

5. See also the section "Barriers to Humanization" below.

6. However, intrinsic and instrumental arguments for humanization need not (necessarily) be mutually exclusive.

7. E.g., greed, disrespect for natural environments, and the widening gaps both nationally and globally between rich and poor.

8. Not "emotion" in the sense advanced by Barrett (1994) as that which incapacitates a person, renders one unable to cope, or that circumvents rational explanations, but in the sense of emotion as "educable".

9. As one of the reviewers pointed out we can meaningfully speak of "educated barbarians", though I'm strongly inclined to think we exceed the limits of language with such expressions. More plausible examples, and ones that help illustrate why I claim "humanization" to be the wider concept might be "educated, but unsocial", "educated, but unfeeling (or insensitive)".

10. I wish to thank one of the reviewers for drawing this critical point to my attention.

11. I have developed these points concerning justice in schooling more fully in Stewart 
(1999). Further implications of justice are raised below in the section, "Barriers to Humanization".

12. Hirst (1993), as is well known, has modified his original position on the forms of knowledge thesis (he now considers practical knowledge rather than theoretical knowledge to be the more fundamental in relation to personal development), but he still holds "that forms of theoretical knowledge can be distinguished in terms of the logical features and truth criteria of the propositions with which they are primarily concerned" (196).

13. As Egan (1996) has recently noted in speaking of Oakeshott, the "conversation" that began "long ago in the jungle and plains of Africa, gathered further voices, perspectives, and varied experiences in the ancient Kingdoms of the East, then additional distinctive voices and experiences in ancient Greece and Rome", is now one of "immense richness, wonder, and diversity" (14).

14. E.g., respect for argument and evidence, curiosity and open-ness to new or alternative views, honesty, perseverance, courage.

15. It is beyond the scope of this paper to work out the details of a curriculum for humanization. Let me say however, that my arguments for humanization as the primary "good" of schooling (in a pluralistic society) would not lead to a situation of "curriculum conformity" across the nation or to culturally insensitive curricula, as some might want to claim it would. There is ample scope within the various traditions or conversations of human thought and feeling to address significant cultural differences of students and to explore the achievements (of mind and heart) in the different cultures of the world all for purposes of individual enrichment. Diverse cultural and ethnic "voices" can readily be examined within the realms (for example) of literature and the arts, as well as the human sciences and religion (assuming, of course, that adequate resources and funding are available). That said, I must also acknowledge the point expressed by Daniels (1993) concerning the central "epistemological role" of schools, and his observation that "one of the major limitations on diversity in the curriculum is that any potential content must be assessed for its capacity ... to improve students' epistemological capacities and increase the likelihood that these capacities will be accompanied by appropriate inclinations" (p.66).

16. For a reminder of the first, see note 4.

17. Concerns about school violence, according to Dolmage (2000), have been greatly exaggerated by the media.

18. There are no history courses (as such) required of Saskatchewan students up to and including grade 9. Any exposure to "history" that elementary and middle years students receive is through social studies. In secondary schooling (grades 10 to 12), students are required to take a course in either History or Social Studies (or Native Studies where available) in each of grades 10,11 and 12 . The net effect is that students can go through the entire K-12 school system in Saskatchewan without taking a single course in history proper (See Saskatchewan Education, 1997; SaskEd web-site).

19. A phenomenon aggravated as well by youngsters' experiences with computer time and the rapidity with which information arrives and changes on the web. 
20. Other examples are problem-solving and decision-making, "skills" which marketdriven models of schooling are anxious to promote (see "Humanization and Schooling: an interlude" above).

21. Partly the result of families struggling to cope with rapid social and technological advances (that are leaving poorer families further and further behind), and of the gradual disappearance of traditional support structures for families.

22. Though pressures of this type are not new to schools. Recall the WCTU had targeted schools in the late $19^{\text {th }}$ and early $20^{\text {th }}$ centuries for "temperance education" to stem the spread of alcohol abuse - a parallel perhaps to the pressure on schools today to teach AIDS education to stem the spread of STD's.

23. An extension of the older idea of a nurse's office located in the school.

\section{References}

Bailin, Sharon; Case, Roland; Coombs, Jerrold; Daniels, Leroi. (1999). Conceptualizing Critical Thinking. Journal of Curriculum Studies, 31(3), 285-302.

Bailey, Charles. (1984). Beyond the Present and Particular: a Theory of Liberal Education. London: Routledge.

Barrett, Richard. (1994). On Emotion as a Lapse from Rationality. Journal of Moral Education, 23(2), 135-43.

Carney, Robert. (1995). Aboriginal Residential Schools Before Confederation: the Early Experience, CCHA, Historical Studies, 61, 13-40.

Child, A. (1978). The Ryerson Tradition in Western Canada, 1871-1906 in Neil McDonald and Alf Chaiton, eds. Egerton Ryerson and his Times. Toronto: Macmillan, 279-301.

Cunningham, Hugh. (1995). Children and Childhood in Western Society Since 1500. London: Longman.

Daniels, Leroi. (1993). Diversity as an Educational Principle. Journal of Curriculum Studies, 25(1), 65-76.

Dewey, John. (1938). Experience and Education. New York: Collier books.

Dewey, John. (1940). How Much Freedom in New Schools in John Dewey, Education Today, ed. J. Ratner. New York: Greenwood Press, 216-223.

Dolmage, Rod. (2000) Lies Damned Lies, and Statistics: the Myths of Youth Violence and Unsafe Schools, Education and Law Journal, 10, 1-46.

Egan, Kieran. (1983). Social Studies and the Erosion of Education. Curriculum Inquiry, 13 (2), 195-214.

Egan, Kieran. (1996). Competing Voices for the Curriculum, in M.F. Wideen and M.C. Courtland, eds. The Struggle for Curriculum: Education, the State and the Corporate Sector. Simon Fraser University: Institute for Studies in Teacher Education, 7-26.

Egan, Kieran. (1997). The Educated Mind: How Cognitive Tools Shape our Understanding.

Chicago: The University of Chicago Press.

Elkind, David. (1995). School and Family in the Postmodern World, Phi Delta Kappan, 72 (1), 8-14 
Entwistle, Harold. (1997). Liberal Education: Elitist and Irrelevant to Everyday Life?. Paideusis: Journal of the Canadian Philosophy of Education Society, 11(1), 7-17.

Hirsch, E.D. (1987). Cultural Literacy: What Every American Needs to Know. Boston: Houghton Mifflin.

Hirst, Paul. (1974). Knowledge and the Curriculum: a Collection of Philosophical Papers. London: Routledge.

Hirst, Paul. (1993). Education, Knowledge and Practices, in Robin Barrow and Patricia White, eds., Beyond Liberal Education: Essays in Honour of Paul H. Hirst. London: Routledge, 184-99.

Kauffman, J.M. and Hallahan, D.P. (eds). (1995). The Illusions of Full In c l u s i o n : a Comprehensive Critique of a Current Special Education Bandwagon. Austin: Pro-ed Publications.

Lupart, Judy L. (2000). "Inching Toward Inclusion: the Excellence/Equity Dilemma in our Schools, in Y. Lenoir, et.als, (eds.), A Pan-Canadian Education Research Agenda. Ottawa: CSSE, 215-31.

Milloy, John S. (1999). A National Crime: the Canadian Government and the Residential School System, 1879 to 1986 . Winnipeg: The University of Manitoba Press.

Nyberg, D. and Egan, K. (1981). The Erosion of Education: Socialization and the Schools. New York: Teachers College Press.

Oakeshott, Michael. (1962). Rationalism in Politics and Other Essays. London: Methuen.

Oakeshott, Michael. (1991). The Voice of Liberal Learning: Michael Oakeshott on Education. Edited by T. Fuller. New Haven: Yale University Press.

Osborne, Ken. (1999). Education: a Guide to the Canadian School Debate - or, Who Wants What and Why?. Toronto: A Penguin/McGill Institute Book.

Peters, R.S. (1966). Ethics and Education. London: George Allen and Unwin Ltd. Peters, R.S. (1977). Education and the Education of Teachers. London: Routledge.

Postman, Neil. (1999). Building a Bridge to the Eighteenth Century: How the Past Can Improve the Future. New York: Alfred Knopf.

Pring, Richard. (1992). Education for a Pluralistic Society, in M. Leicester and M.E. Taylor, (eds). Ethics, Ethnicity and Education. London: Kogan Page, 19-30.

Pring, Richard. (1995). Closing the Gap: Liberal Education and Vocational Preparation. London: Hodder and Stoughton.

Rorty, Richard. (1996). Education Without Dogma: Truth, Freedom and our Universities, in Wm. Hare and John Portelli, eds., Philosophy of Education: Introductory Readings $\left(2^{\text {nd }}\right.$ edition). Calgary: Detselig, 207-17.

Saskatchewan Education. (June 1997). Core Curriculum: an Information Bulletin for Administrators. Regina: Author.

Saskatchewan Education. www.sasked.gov.sk.ca/docs

Sheehan, Nancy. (1981). WCTU on the Prairies, 1886-1930: an Alberta-Saskatchewan Comparison. Prairie Forum, VI(1).

Siegel, Harvey. (1993). Not by Skill Alone: the Centrality of Character to Critical Thinking, 
Informal Logic, XV(3), 163-76.

Stewart, Douglas. (1999). Schooling, Justice, and Education: a Policy Paper. Prepared for Saskatchewan School Trustees Association. Saskatchewan Instructional Development and Research Unit, University of Regina.

Tomkins, G.S. (1986). A Common Countenance: Stability and Change in the Canadian Curriculum. Scarborough ON: Prentice-Hall Canada Inc.

White, John. (1995). Education and Personal Well-Being in a Secular Universe. An Inaugural Lecture delivered at the Institute of Education University of London, 16 November 1994. London: Institute of Education. 